\title{
HITUNG JUMLAH BAKTERI COLIFORM PADA DEPOT AIR MINUM ISI ULANG DENGAN MENGGUNAKAN METODE MPN DI KECAMATAN KOTA TERNATE TENGAH
}

\section{THE COUNT NUMBER OF COLIFORM BACTERIA IN REFILL DRINGKING WATER DEPOT USING MPN AT DISTRICT AREA OF CENTRAL TERNATE CITY}

\author{
Aan Yulianingsih, Indah Djumati \\ Jurusan Teknologi Laboratorium Medis, Poltekkes Kemenkes Ternate \\ *E-mail Korenspondensi : aanyulianingsih@rocketmail.com
}

\begin{abstract}
Refill drinking water is drinking water that has gone through a filtering and sterilization process and can be drunk immediately. The maximum permissible level for total Coliform bacteria contained in drinking water is 0 MPN / $100 \mathrm{ml}$, in accordance with the Minister of Health Regulation No. 492 / Menkes / Per / IV / 2010 April 19, 2010 concerning Drinking Water Quality Requirements, if drinking water is available Coliform bacteria in it will cause disease. This study aims to identify the number of Coliform bacteria in refill drinking water in the District of Central Ternate City and to determine whether the refill drinking water meets the bacteriological quality standards of water. This research uses descriptive analytic method by conducting laboratory tests to determine the number of Coliform bacteria in refill drinking water. The number of samples taken was 26 samples taken by random sampling. The results showed that there were 8 refill drinking water depots (30.7\%) identified the presence of coliform bacteria, Enterobacter and Escerchia coli and there was no relationship between the discovery of bacteria with the depot operating duration $(p=0.655>0.05)$, the discovery of bacteria with filter change $(p=0.139>0.05)$ and the discovery of bacteria with the type of water sample used ( $p=$ $0.425>0.05$ ). It is recommended for people who often consume refill drinking water in depots around, especially in the District of Central Ternate, to be more careful in consuming refilled drinking water, by looking at the quality of the drinking water depot itself, whether it has been certified from a health institution or no, so that more guarantees the quality of drinking water consumed
\end{abstract}

Key word: Escherichia coli, Enterobacter, Refill Drinking Water Depot, MPN

\section{ABSTRAK}

Air Minum Isi Ulang adalah air minum yang telah melalui proses penyaringan dan proses sterilisasi dan dapat langsung diminum. Kadar maksimum yang diperbolehkan untuk Total Bakteri Coliform yang terdapat di dalam air minum yaitu 0 MPN/100 ml, sesuai dengan Peraturan Menteri Kesehatan Nomor 492 / Menkes / Per / IV / 2010 Tanggal 19 April 2010 tentang Persyaratan Kualitas Air Minum, jika air minum terdapat bakteri coliform didalamnya akan menyebabkan penyakit. Penelitian ini bertujuan untuk mengidentifikasi jumlah bakteri Coliform pada air minum isi ulang yang ada di wilayah Kecamatan Kota Ternate Tengah dan untuk menentukan apakah air minum isi ulang ini sudah memenuhi standar mutu bakteriologis air. Penelitian ini menggunakan metode deskriptif analitik dengan melakukan uji laboratorium untuk mengetahui jumlah bakteri Coliform pada air minum isi ulang. Jumlah sampel yang diambil sebanyak 26 sampel yang diambil secara random sampling. Hasil penelitian menunjukkan terdapat 8 depot air minum isi ulang (30,7\%) teridentifikasi adanya bakteri coliform yaitu Enterobacter dan Escerchia coli dan Tidak ada hubungan antara penemuan bakteri dengan lama beroperasi depot $(p=0,655>0,05)$, penemuan bakteri dengan pergantian penyaring $(p=0,139>0,05)$ dan penemuan bakteri dengan jenis sampel air yang digunakan $(p=0,425>0,05)$ Disarankan bagi masyarakat yang sering mengkonsumi air minum isi ulang yang terdapat di depot-depot sekitar khususnya di Kecamatan Kota Ternate Tengah, agar lebih teliti dalam mengkonsumsi air minum isi ulang, dengan melihat kualitas depot air minum itu sendiri, apakah sudah tersertifikasi dari lembaga kesehatan atau tidak, sehingga lebih menjamin kualitas dari air minum yang dikonsumsi.

Kata kunci: Escherichia coli, Enterobacter, Depot Air Minum Isi Ulang, MPN

\section{PENDAHULUAN}

Air adalah materi esensial di dalam kehidupan. Tidak satupun makhluk hidup di dunia ini yang tidak memerlukan dan tidak mengandung air. Sel hidup, baik tumbuhan maupun hewan, sebagian besar tersusun oleh air, seperti di dalam sel tumbuhan terkandung lebih dari $75 \%$ atau didalam sel hewan terkandung lebih dari $67 \%$. Keperluan sehari-hari terhadap air, berbeda untuk tiap tempat dan untuk tiap tingkatan kehidupan. Yang jelas semakin tinggi taraf kehidupan, semakin meningkat jumlah keperluan akan air (Departemen Kesehatan, 1994).

Air minum dalam kemasan (AMDK) yang disebut-sebut menggunakan air pegunungan banyak dikonsumsi. Namun harga AMDK dari berbagai merek yang terus meningkat membuat konsumen mencari alternatif baru yang murah yaitu air minum isi 
ulang. Air minum yang bisa diperoleh di depot-depot itu harganya bisa sepertiga dari produk air minum dalam kemasaan yang bermerek. Karena itu banyak rumah tangga beralih pada layanan ini. Hal inilah yang menyebabkan depot-depot air minum isi ulang bermunculan. Keberadaan depot air minum isi ulang terus meningkat sejalan dengan dinamika keperluan masyarakat terhadap air minum yang bermutu dan aman untuk dikonsumsi. Meski lebih murah, tidak semua depo air minum isi ulang terjamin keamanan produknya. Hasil pengujian laboratorium yang dilakukan Badan Pengawas Obat dan Makanan (POM) atas kualitas depot air minum isi ulang di Jakarta menunjukkan adanya cemaran mikroba dan logam berat pada sejumlah contoh (Kompas, 2003).

Berdasarkan Peraturan Menteri Kesehatan Republik Indonesia No.736/ MENKES/IV/2010 tentang Tata Laksana Pengawasan Kualitas Air Minum, bahwa pengawasan pada depot air minum harus sesuai dengan Peraturan Menteri Kesehatan yang mengatur tentang tata cara pengawasan kualitas air minum, yaitu harus dilakukannya pemeriksaan internal maupun eksternal secara berkala pada depot air minum. Kadar maksimum yang diperbolehkan untuk Total Bakteri Coliform yang terdapat di dalam air minum yaitu 0 MPN/100 ml, kandungan bakteri Escherecia Coli dalam air minum yaitu 0/100 ml. oleh sebab itu Air bersih dan air minum tidak boleh melebihi persyaratan yang telah ditentukan apabila dalam air minum dan air bersih sudah tercemar bakteri Escherecia Coli maupun Total Coliform yang melebihi persyaratan maka akan menyebabkan penyakit diare. (Kementerian Kesehatan, 2010).

Ternate merupakan salah satu daerah yang berada di Maluku Utara, dimana didaerah Ternate banyak terdapat depotdepot air minum isi ulang dan masyarakat daerah Ternate banyak yang mengkonsumsi air minum isi ulang disamping efisien juga harganya yang relative murah sehingga bisa dijangkau oleh seluruh lapisan masyarakat dan belum ada jurnal yang membahas tentang Bakteri Coliform pada depot air yang terdapat di daerah Ternate.

Berdasarkan hal tersebut diatas maka penelitian ini bertujuan untuk melihat dan meghitung Jumlah Bakteri Coliform pada Depot Air Minum Isi Ulang (DAMIU) dengan Menggunakan Metode Most Probable
Number (MPN) di Kecamatan Kota Ternate Tengah.

\section{METODE}

\section{Desain, tempat dan waktu}

Penelitian ini dilakukan dengan metode Desktiptif analitik. Penelitian dilakukan di Ternate Tengah dengan sampel yang diperoleh dari Depot air minum isi ulang yang berada di Kota Ternate Tengah. Teknik pemeriksaannya dilakukan di Laboratorium Terpadu Poltekkes Kemenkes Ternate dan dilakukan pada bulan September-Oktober 2019.

\section{Alat dan Bahan}

Laminar air flow, autoclave, oven, incubator, Air minum isi ulang yang berasal dari depot, media BGLB, media LB, Media EC Broth, Media Endo Agar, Media TSIA, Media SIM, Media Citrat, Media Urea, Media MrVp, media LIA, media glukosa, media laktosa, media sukrosa, media manitol, media malonat, larutan $\mathrm{KOH} \mathrm{40 \% ,} \mathrm{reagent} \mathrm{kovaks,}$ alphanaftol $5 \%$.

\section{Prosedur Penelitian}

Pengambilan sampel air dilakukan dengan cara Kran air pada depot dibersihkan dan dibuka lebar 1 - 2 menit lalu Kran ditutup rapat dan mulut kran disterilkan. Setelah itu, Kran dibuka sedikit sehingga air mengalir pelan lalu dibuka tali pembungkus botol, dibuka tutup botol dan Air kran ditampung $3 / 4$ botol. Setelah itu, Botol ditutup dan tutup dibungkus kertas steril, diikat dengan tali dan diberi label.

Untuk metode analitik menggunakan Metode MPN yang digunakan adalah 5.1.1. Dimana, setiap sampel air dipipet sebanyak $10 \mathrm{ml}$ dimasukkan ke dalam lima tabung berisi media LB, $1 \mathrm{ml}$ ke tabung ke- 6 dan 0,1 $\mathrm{ml}$ ke tabung 7 . Setelah itu diinkubasi selama 24-48 jam $37^{\circ} \mathrm{C}$ (Diamati adanya kekeruhan dan terbentuknya gas pada media LB). Pada tabung di media LB yang positif diambil satu mata ose dan ditanam ke media BGLB, diinkubasi selama $24-48$ jam $37^{\circ} \mathrm{C}$. Ambil satu mata ose dari media BGLB (terdapat kekeruhan dan gas), tanam ke media EC broth dan Endo Agar inkubasi selama 24-48 jam $37^{\circ} \mathrm{C}$. Amati pertumbuhan koloni yang tumbuh, lalu dilanjutkan ke uji biokimia bakteri (Media TSIA, Media SIM, Media Citrat, Media Urea, Media MrVp, media LIA, media glukosa, media laktosa, media sukrosa, media manitol, media malonat) kemudian di inkubasi pada suhu $37^{\circ} \mathrm{C}$ selama $1 \times 24$ jam. 
Untuk mengetahui spesies dari bakteri maka hasil yang terbentuk dicocokkan dengan tabel uji biokimia bakteri.

\section{Pengolahan dan Analisis Data}

Data yang diperoleh disajikan dalam bentuk tabel dan dijelaskan secara deskriptif dengan menggunakan tabel perbandingan MPN dan hubungan antara variabel di uji dengan menggunakan uji statistik koefisien korelasi.

\section{HASIL}

Berdasarkan hasil pemeriksaan di Laboratorium Terpadu Poltekkes Kemenkes Ternate, dari 26 sampel air di 26 Depot Air Minum Isi Ulang di wilayah Kecamatan Kota Ternate Tengah. Setiap depot terdiri dari dua sampel air yang berbeda, yaitu sampel air yang sudah disterilisasi (Air Minum) dan sampel air yang belum disterilisasi (Air Baku), maka diperoleh hasil pemeriksaan dari 26 depot air minum isi ulang, terdapat 8 depot yang teridentifikasi airnya mengandung bakteri coliform, yaitu bakteri $E$ coli dan Enterobacter (tabel 1).

Hubungan antara pertumbuhan bakteri dengan lama depot beroperasi menunjukkan tidak ada hubungan dengan nilai $p=0,655>$ 0,05 (tabel 2).

Hubungan antara pertumbuhan bakteri dengan jadwal pergantian penyaring pada depot air minum yang ada di Kecamatan Kota Ternate Tengah menunjukkan tidak ada hubungan dengan nilaip $\mathrm{p}=0,139>0,05$ (tabel 3).

Hubungan antara pertumbuhan bakteri dengan jenis sampel air pada depot air minum yang ada di Kecamatan Kota Ternate Tengah menunjukkan tidak ada hubungan dengan nilai $p=0,425>0,05$ (tabel 4 ).

\section{PEMBAHASAN}

Pada penelitian ini dari 26 depot didapatkan hasil sebanyak 8 depot yang teridentifikasi airnya mengandung bakteri coliform.

$$
\text { Berdasarkan hasil penelitian }
$$
sebelumnya Rumondor, dkk (2017) menunjukkan bahwa dari 20 depot air minum isi ulang di Kota Manado yang telah memenuhi kriteria inklusi dan diidentifikasi menggunakan media kultur, ditemukan bakteri Enterobacter, pseudomonas, Bacillus dan bakteri lainya.

Pada hubungan antara pertumbuhan bakteri dengan waktu penggantian penyaringan (filter) 1 bulan sekali didapatkan hasil tidak ada hubungan. Hal ini sejalan dengan penelitian yang dilakukan oleh Widyastuti, et all (2016) yang mengatakan bahwa media filter yang digunakan oleh masing-masing depot berbeda sehingga setiap filter yang digunakan juga mempunyai kualitas yang berbeda. Filtrasi pada DAM dilakukan secara bertingkat dari media filter berpori-pori besar ke media filter berpori-pori lebih kecil. Efektifitas filter pada DAMIU tergantung pada kualitas air baku, semakin baik kualitas air baku maka masa pakai filter akan semakin lama, karena daya saring filter tidak terlalu berat dengan kata lain tingkat kejernihan air baku akan mempengaruhi filter, semakin keruh air baku semakin berat kerja filter, sehingga hasil proses penyaringan dapat kurang optimal. Hal ini juga sejalan dengan wawancara yang dilakukan oleh tim peneliti bahwa pemilik depot air minum isi ulang mengganti filter (penyaring) berdasarkan banyaknya produksi air minum isi ulang, dimana semakin sering depot memproduksi air minum isi ulang maka semakin sering pula filternya diganti.

Pada hubungan antara pertumbuhan bakteri dengan lama depot beroperasi didapatkan hasil tidak ada hubungan. Pada hubungan antara sumber air baku dengan pertumbuhan bakteri didapatkan hasil tidak ada hubungan. Menurut hasil penelitian Alfina dan Laode (2017), bahwa sumber air baku tidak berhubungan dengan pertumbuhan bakteri tetapi yang berhubungan adalah lamanya air baku tersebut disimpan dalam bak penampungan. Hal ini juga sejalan dengan wawancara yang dilakukan oleh tim peneliti dimana bak penampungan air baku pada depot air di bersihkan tiap hari dan air yang berada dalam bak penampungan paling lama dua hari.

\section{KESIMPULAN}

Dari 26 depot air minum isi ulang, terdapat 8 depot air minum isi ulang yang teridentifikasi adanya bakteri coliform yaitu Enterobacter dan Escerchia coli.

\section{SARAN}

1. Bagi masyarakat yang sering mengkonsumi air minum isi ulang yang terdapat di depot-depot sekitar khususnya di Kecamatan Kota Ternate Tengah, agar lebih teliti dalam mengkonsumsi air minum isi ulang, dengan melihat kualitas depot air minum itu sendiri, apakah sudah tersertifikasi dari lembaga kesehatan atau tidak, 
sehingga lebih menjamin kualitas dari air minum yang dikonsumsi.

2. Sistem pengolahan air minum depot sebaiknya mendapatkan sertifikasi dari lembaga yang memiliki kompetensi, sehingga mendapatkan hasil dan untuk ditindaklanjuti, agar air minum tersebut benar-benar memenuhi standar mutu bakteriologis air minum.

\section{UCAPAN TERIMA KASIH}

Ucapan terima kasih kami sampaikan kepada kepada pihak Poltekkes Kemenkes Ternate yang telah memberikan kesempatan dan bantuan untuk melakukan penelitian ini.

\section{DAFTAR PUSTAKA}

Athena, dkk. 2004. Kandungan Pb, Cd, Hg dalam Air Minum dari Depot Air Minum Isi Ulang di Jakarta, Tenggerang dan Bekasi. Jurnal Ekologi Kesehatan 3(3) : 148-152.

Depkes RI. 2006. Pedoman Pelaksanaan Penyelenggaraan Hygiene Sanitasi Depot Air Minum. Ditjen PP dan PL, Jakarta.

Eria, F. dan Budi, H. 2015. Hubungan Keberadaan Eserchia coli pada depot air minum isi ulang dengan kejadian diare pada balita penggunaannya di Kecamatan Jatinegara. Departemen Fakultas Kesehatan Masyarakat, Universitas Indonesia. Jakarta.
Kementrian Kesehatan Republik Indonesia. 2010. Persyaratan Kualitas Air Minum. Peraturan Menteri Kesehatan Republik Indonesia nomor 492/Menkes/IV/2010. Depkes RI, Jakarta.

Kementerian Kesehatan Republik Indonesia. 2015. Sanitasi dan Air Minum yang Layak Kurangi Resiko Diare Hingga 94\%. www.depkes.go.id.

Lim, D. 1998. Microbiology. McGraw Hill Publishing Company, New York : 91.

Notoatmodjo, S. 2003. Pendidikan dan Perilaku Kesehatan. Rineka Cipta : Jakarta.

Rahadi, U.S.E. 2011. Isolasi Eschericia coli dari Daging Sapi yang dijual di Pasar Tradisional Surabay Selatan. Fakultas Kedokteran Hewan, Universitas Erlangga. Surabaya.

Rumondor, P.P., dkk. 2014. Identifikasi Bakteri pada depot air minum isi ulang di kota Manado. Jurnal eBiomedik(eBM), Vol 2, No 2.

Us. Departement of Health and Human Service. 2005. Health Consultation : Walden's Ridge Utlity District Signal Mountain, Hamilton Country. Tennessee Departement of Health Under a Cooperative Agreement with The Agency for Toxic Substances and Disease Registry. 
Tabel 1. Hasil Perhitungan Jumlah Bakteri Coliform Pada Depot Air Minum Isi Ulang.

\begin{tabular}{|c|c|c|c|c|c|c|}
\hline \multirow[b]{2}{*}{ No } & \multirow[b]{2}{*}{$\begin{array}{c}\text { Kode } \\
\text { Sampel }\end{array}$} & \multicolumn{3}{|c|}{ Hasil BGLB } & \multirow{2}{*}{$\begin{array}{l}\text { Indeks } \\
\text { MPN per } \\
100 \mathrm{ml}\end{array}$} & \multirow[b]{2}{*}{ Ket } \\
\hline & & $\begin{array}{c}5 \times 10 \\
\mathrm{ml}\end{array}$ & $1 \times 1 \mathrm{ml}$ & $1 \times 0,1 \mathrm{ml}$ & & \\
\hline 1 & $1 \mathrm{~A}$ & 1 & 0 & 0 & 2 & E. coli \\
\hline 2 & 1B & 4 & 1 & 0 & 22 & E. coli \\
\hline 3 & $2 \mathrm{~A}$ & 2 & 0 & 0 & 5 & E. aerogenes \\
\hline 4 & $2 \mathrm{~B}$ & 3 & 0 & 0 & 9 & E. aerogenes \\
\hline 5 & $3 A$ & 1 & 0 & 0 & 2 & E. aerogenes \\
\hline 6 & $3 B$ & 2 & 1 & 1 & 10 & E. aerogenes \\
\hline 7 & $4 \mathrm{~A}$ & 2 & 0 & 0 & 5 & E. aerogenes \\
\hline 8 & $4 \mathrm{~B}$ & 4 & 1 & 1 & 27 & E. aerogenes \\
\hline 9 & $5 A$ & 2 & 0 & 0 & 5 & E. aerogenes \\
\hline 10 & $5 B$ & 2 & 0 & 0 & 5 & E. aerogenes \\
\hline 11 & $6 \mathrm{~A}$ & 4 & 0 & 0 & 17 & E. aerogenes \\
\hline 12 & $6 \mathrm{~B}$ & 4 & 0 & 0 & 17 & E. aerogenes \\
\hline 13 & $7 \mathrm{~A}$ & 0 & 0 & 0 & 0 & - \\
\hline 14 & $7 \mathrm{~B}$ & 0 & 0 & 0 & 0 & - \\
\hline 15 & $8 \mathrm{~A}$ & 0 & 0 & 0 & 0 & - \\
\hline 16 & $8 \mathrm{~B}$ & 0 & 0 & 0 & 0 & - \\
\hline 17 & $9 \mathrm{~A}$ & 0 & 0 & 0 & 0 & - \\
\hline 18 & $9 \mathrm{~B}$ & 0 & 0 & 0 & 0 & - \\
\hline 19 & $10 \mathrm{~A}$ & 0 & 0 & 0 & 0 & - \\
\hline 20 & $10 \mathrm{~B}$ & 0 & 0 & 0 & 0 & - \\
\hline 21 & $11 \mathrm{~A}$ & 0 & 0 & 0 & 0 & - \\
\hline 22 & 11B & 0 & 0 & 0 & 0 & - \\
\hline 23 & $12 \mathrm{~A}$ & 0 & 0 & 0 & 0 & - \\
\hline 24 & 12B & 0 & 0 & 0 & 0 & - \\
\hline 25 & $13 \mathrm{~A}$ & 0 & 0 & 0 & 0 & - \\
\hline 26 & 13B & 0 & 0 & 0 & 0 & - \\
\hline 27 & $14 \mathrm{~A}$ & 1 & 0 & 0 & 2 & - \\
\hline 28 & 14B & 0 & 0 & 0 & 0 & - \\
\hline 29 & $15 \mathrm{~A}$ & 2 & 1 & 1 & 10 & - \\
\hline 30 & 15B & 0 & 0 & 0 & 0 & - \\
\hline 31 & $16 \mathrm{~A}$ & 2 & 1 & 1 & 10 & - \\
\hline 32 & 16B & 0 & 0 & 0 & 0 & - \\
\hline 33 & $17 \mathrm{~A}$ & 0 & 0 & 0 & 0 & - \\
\hline 34 & 17B & 2 & 0 & 0 & 5 & E. aerogenes \\
\hline 35 & $18 \mathrm{~A}$ & 0 & 0 & 0 & 0 & - \\
\hline 36 & $18 \mathrm{~B}$ & 0 & 0 & 0 & 0 & - \\
\hline 37 & $19 \mathrm{~A}$ & 0 & 0 & 0 & 0 & - \\
\hline 38 & 19B & 0 & 0 & 0 & 0 & - \\
\hline 39 & $20 \mathrm{~A}$ & 0 & 0 & 0 & 0 & - \\
\hline 40 & $20 \mathrm{~B}$ & 0 & 0 & 0 & 0 & - \\
\hline 41 & $21 \mathrm{~A}$ & 0 & 0 & 0 & 0 & - \\
\hline 42 & 21B & 0 & 0 & 0 & 0 & - \\
\hline 43 & $22 \mathrm{~A}$ & 2 & 1 & 0 & 8 & E. aerogenes \\
\hline 44 & $23 \mathrm{~B}$ & 3 & 0 & 1 & 13 & E. aerogenes \\
\hline 45 & $24 \mathrm{~A}$ & 0 & 0 & 0 & 0 & - \\
\hline 46 & $24 B$ & 0 & 0 & 0 & 0 & - \\
\hline 47 & $25 \mathrm{~A}$ & 0 & 0 & 0 & 0 & - \\
\hline 48 & $25 \mathrm{~B}$ & 0 & 0 & 0 & 0 & - \\
\hline 49 & $26 \mathrm{~A}$ & 0 & 0 & 0 & 0 & - \\
\hline 50 & $26 \mathrm{~B}$ & 0 & 0 & 0 & 0 & - \\
\hline
\end{tabular}




\begin{tabular}{lllllll}
\hline 51 & $26 \mathrm{~A}$ & 0 & 0 & 0 & 0 & - \\
\hline 52 & $26 \mathrm{~B}$ & 0 & 0 & 0 & 0 & - \\
\hline
\end{tabular}

Ket :

E. coli $=$ Escherichia coli

E. aerogenes $=$ Enterobacter aerogenes

Tabel 2. Hubungan Pertumbuhan Bakteri dengan Lama Depot Beroperasi

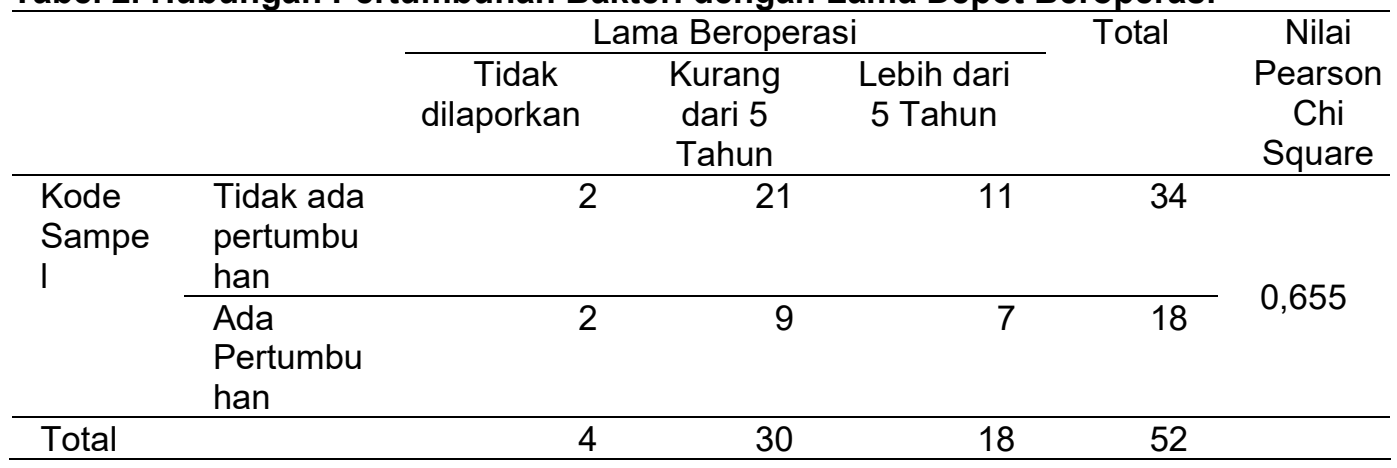

Tabel 3. Hubungan Pertumbuhan Bakteri dengan Waktu Penggantian Penyaringan

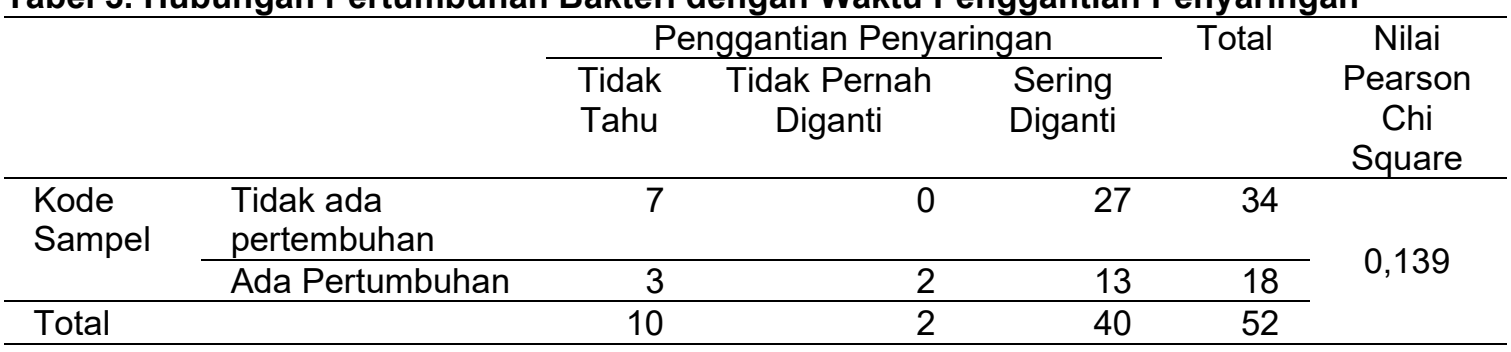

Tabel 4. Hubungan Pertumbuhan Bakteri dengan Jenis Sampel

\begin{tabular}{|c|c|c|c|c|c|}
\hline & & \multicolumn{2}{|c|}{ Jenis Sampel } & \multirow[t]{2}{*}{ Total } & \multirow{2}{*}{$\begin{array}{c}\text { Nilai } \\
\text { Pearson } \\
\text { Chi } \\
\text { Square }\end{array}$} \\
\hline & & PDAM & Sumur & & \\
\hline \multirow[t]{2}{*}{$\begin{array}{l}\text { Kode } \\
\text { Sampel }\end{array}$} & $\begin{array}{l}\text { Tidak ada } \\
\text { pertembuhan }\end{array}$ & 25 & 9 & 34 & \multirow{3}{*}{0,425} \\
\hline & Ada Pertumbuhan & 15 & 3 & 18 & \\
\hline Total & & 40 & 12 & 52 & \\
\hline
\end{tabular}

